\title{
Engineering at the Service of Corruption: The Response of Technological Courts
}

\author{
Fábio Márcio Bisi Zorzal*, Dariane Miranda Pereira and Thiago Gomes Ferreira \\ Federal Institute of Education, Science and Technology of Espírito Santo, Brazil
}

*Corresponding author: Fábio Márcio Bisi Zorzal, Federal Institute of Education, Science and Technology of Espírito Santo, Brazil.

Received Date: April 08, 2019

Published Date: April 18, 2019

\section{Opinion}

The energy that is spent in Brazil to fight corruption is greater than its continental size. In financial terms, it consumes significant portions, which surpass even the production costs. This was the speech impulse of the last presidential election campaign, suggesting a reduction target from $20 \%$ to $30 \%$ of the then current levels. Part of that was seen in works that would be delivered to the World Cup and the Olympics, such as lines of subways, buses, and its stations, as well as airfields and the "Lava Jato" operation. However, The Union Accounts Court's report indicated twelve thousand works in the country (TCU, 2018). Meanwhile, several states worked in red and in a more serious situation was the State of Rio de Janeiro, which was the biggest stage of these investments. Now, assuming the constructions as the central elements of these events, work was left to engineering in the broadest sense, that actually lashed out, corrupting the design, modeling, budgeting, scheduling and other services in support of this sad legacy. This for sure. In this context, it also includes the technicians who guided the contracting agencies, including the role of tax in a promiscuous link to the detriment of a contradicted society.

In terms of private enterprise, it is not different, as an example there are the dam collapses, which are causing the greatest Brazilian environmental disasters, heritage and lives are being disrupted, and there are many others in imminent danger. The agenda differs in mismatch between the obligation to spend and what you want in return on investment, exchanging the good engineering technique for the best economical technique. Reports have been made on this line, judging the market rather than the low or no legal effectiveness. However, the other monitoring and control organs, which are functionally established to combat corruption and the diversion of resources, even if guide contrary to the cause, little or nothing can do, since they have no resources to match the volume of works that turned the momentum of meeting deadlines in sharp deviation of purpose. Dependent brown opinions, strange to his legalistic universe, found themselves limited in the challenges of the time, losing the opportunity and convenience for the lack of his hand-work misaligned with demand. Palliative this innovation may be carried engineer shaped \& il CEDC; complement shall lawyer, although in the broad sense level, as the rare existing arbitration chambers have the same connotation of this what is intended, not to mention the scope of its jurisdictional.

Now, in this opinion, the debate is by the same engineering, and it should stay. The gene is sheeted in tension tests to be taken as the basis of evidence, usually mandating samples, field trials, regulatory binding sometimes viciously removed under execution, embodied in technical reports and accusatory directions, at least in Brazil. In this line, the debate would become exceedingly fast and mature own instance of technical and technological progress. Today, the solution is based in recursive debates that went to the legal field, the only agenda that allows maximize the discussion out of the field of engineering and eloquence postpone decisions that do not serve justice, though full of law. The focus is changed of the speech originating from technical issues to other purely legal, but political and strategic, departing from the merit in discussion for what would be the socially acceptable outlet for demand. As spare this is the legacy mentioned, and defense attorneys stands perched over and a half and not the end, overwhelm courts, pending, slow in the clash and debate these solutions. Now numbering eighty million of them last year (CNJ, 2018), without a specific focus on engineering, $94 \%$ of them in the first instance, unprepared for the social expected speed. It is in this line that is clearly seen the lack of connection with a stronger role of engineering, both in line accusatory typically established by the attorney-client basis for prosecution, as in line 
with the judgment prominently made by the same basic judges, lay in the affairs of this technological nature. Despite corruption including entering the prosecutors and courts, at least potentially the problem of genetic technology would decisoriamente affected by specialty, whose results would be controversial and guided only by the technical advice this technology instance.

This will be a paradigm shift, and who knows if desired abstemious legal tint occasion, read: convenience, to establish clean perhaps in the technical field, where the foundation is another. In this view, the engineering is renewed, strengthening pragmatically the new course of these tried and may be resumed at the point desirable in its operational base, aiming to impregnate the success of technology-legal jurisprudence. Meanwhile the works delivered are obsolete, scraps, and out of purposes, debit, calling themselves white elephant. And the bill was. Some senators estimated 700 billion reais, maturing over the next 40 years as blunt this recent history. Part of it was leveraged with the new pension policy, soon to leave the virtual plane in temporary sums to cash, providing public budgets, leveraging and renewing the economy. This is roughly equivalent to adding 10 to 15 more years of work in the economically active population. Therefore, the account falls on the society of palliative and emergency basis, shifted from the those responsible for the low which benefits the corrupt cause, and who perseveres unscathed to traffic this reading.

\section{Acknowledgment}

None.

\section{Conflict of Interest}

No conflict of interest. 